\title{
Genetic Variability in Adenosine Deaminase-Like Contributes to Variation in Alcohol Preference in Mice
}

\author{
Heidi M. B. Lesscher (iD, Alexis Bailey, and Louk J. M. J. Vanderschuren
}

\begin{abstract}
Background: A substantial part of the risk for alcohol use disorder is determined by genetic factors. We previously used chromosome substitution (CSS) mice, to identify a quantitative trait loci (QTL) for alcohol preference on mouse chromosome 2 . The aim of this study was to identify candidate genes within this QTL that confer the risk for alcohol preference.

Methods: In order to delineate the neurobiological underpinnings of alcohol consumption, we expanded on the QTL approach to identify candidate genes for high alcohol preference in mice. We narrowed down a QTL for alcohol preference on mouse chromosome 2, that we previously identified using CSS mice, to 4 candidate genes in silico. Expression levels of these candidate genes in prefrontal cortex, amygdala, and nucleus accumbens - brain regions implicated in reward and addiction-were subsequently compared for the CSS-2 and the C57BL/6J host strain.

Results: We observed increased expression of adenosine deaminase-like (Adal) in all 3 regions in CSS-2 mice. Moreover, we found that the adenosine deaminase inhibitor EHNA reduced the difference in alcohol preference between CSS-2 and C57BL/6J mice.

Conclusions: This study identifies Adal as a genetically protective factor against alcohol consumption in mice, in which elevated Adal levels contribute to low alcohol preference.

Key Words: Adenosine, Alcohol, Quantitative Trait Loci, Preference, Mice.
\end{abstract}

A LCOHOL USE DISORDERS (AUD) are an enormous public health problem, affecting over 76 million people worldwide (WHO, 2011). The risk for AUD is determined for a substantial part by genetic factors. Twin and adoption studies have demonstrated greater risk for alcoholrelated disorders in individuals who have an affected monozygotic twin, as compared to individuals with an affected dizygotic twin (Ystrom et al., 2011). From these studies, the heritability for AUD has been estimated to be 48 to $71 \%$.

Human genomewide association studies and rodent genetic mapping studies have yielded profound insight into the molecular mechanisms underlying the individual risk for AUD. For example, inbred mouse strains, which are well characterized both genetically and behaviorally, have been used to discern the genetic components underlying the vulnerability for AUD. Indeed, multiple quantitative trait loci (QTL) for alcohol intake and/or preference have been identified (Bubier et al., 2014; Gill and Boyle, 2005; Lesscher et al.,

From the Division of Behavioural Neuroscience (HMBL, LJMJV), Department of Animals in Science and Society, Faculty of Veterinary Medicine, Utrecht University, Utrecht, the Netherlands; and Institute of Medical and Biomedical Education (AB), St George's University of London, London, UK.

Received for publication December 7, 2016; accepted April 20, 2017.

Reprint requests: Heidi M. B. Lesscher, PhD, Division of Behavioural Neuroscience, Department of Animals in Science and Society, Faculty of Veterinary Medicine, Utrecht University, Yalelaan 2, 3584 CM Utrecht, the Netherlands; Tel.: +31-30-253-9876; Fax: +31-30-253-7997; E-mail:H.M.B.Lesscher@uu.nl

Copyright $(2017$ by the Research Society on Alcoholism.

DOI: 10.1111/acer.13409 2009a; Phillips et al., 1998; Rodriguez et al., 1995; Vadasz et al., 2000; Whatley et al., 1999). In-depth QTL analyses have revealed specific genes that contribute to the risk for alcohol consumption and AUD (Bubier et al., 2014; Milner and Buck, 2010).

We previously used chromosome substitution (CSS) mice (Nadeau et al., 2000), to identify a grandparent-dependent QTL for alcohol preference on mouse chromosome 2. Chromosome 2 was chosen as our focal point because QTLs for high alcohol consumption were previously identified on this chromosome. CSS-2 mice, in which chromosome 2 from the $\mathrm{A} / \mathrm{J}$ donor strain was introduced into the genome of C57BL/ $6 \mathrm{~J}$ mice, displayed a low preference for alcohol compared to C57BL/6J mice (Lesscher et al., 2009a). CSS-2 mice were however not different from $\mathrm{C} 57 \mathrm{BL} / 6 \mathrm{~J}$ mice in taste preference for sweet and bitter solutions nor in the metabolism rate of alcohol. In this study, we expanded on this QTL approach to identify quantitative trait genes (QTG) that confer the risk for alcohol preference. Therefore, we narrowed down the QTL on chromosome 2 in silico to identify candidate genes. To select QTGs (i) we first selected coding single nucleotide polymorphisms (SNPs) within the QTL, (ii) we then selected genes that are expressed in the brain and subsequently filtered those genes with expression in brain regions that have been associated with reward and addictive behavior, that is, the prefrontal cortex $(\mathrm{PFc})$, amygdala $(\mathrm{AMG})$, and nucleus accumbens (NAc), and (iii) we further selected genes for which literature was available to support their role in (reward-related) behavior (Abiola et al., 2003; Korstanje and Paigen, 2002; Nikolskiy et al., 2015; Noyes et al., 2011). Subsequently, expression levels of these candidate genes in the 
$\mathrm{PFc}, \mathrm{AMG}$, and NAc - brain regions widely implicated in the positive subjective and addictive properties of substances of abuse (e.g., Everitt and Robbins, 2013; Koob and Volkow, 2010; Tabakoff and Hoffman, 2013) - were compared for the CSS-2 and C57BL/6J host strain. Finally, using a pharmacological approach, the functional role of the most prominent candidate gene, adenosine deaminase-like (Adal) in the regulation of alcohol consumption in CSS-2 mice was determined.

\section{MATERIALS AND METHODS}

\section{Animals}

$\mathrm{C} 57 \mathrm{BL} / 6 \mathrm{~J}, \mathrm{~A} / \mathrm{J}$, and $\mathrm{C} 57 \mathrm{BL} / 6 \mathrm{~J}-\mathrm{Chr} 2^{\mathrm{A}} / \mathrm{NaJ}$ (referred to as CSS-2) (Nadeau et al., 2000) mice were obtained from Jackson Laboratory (Bar Harbor, ME) and bred in our department. Experimental animals were male mice, 8 to 10 weeks old at the onset of testing. The mice were group-housed with mice from the same genotype under controlled conditions $\left(20 \pm 2^{\circ} \mathrm{C}\right.$ and 50 to $70 \%$ humidity), and they were acclimatized to a 12 -hour light/dark cycle (lights off at 7:00 AM) for at least 2 weeks prior to testing. Food and water were available ad libitum. The experimental procedures were approved by the Animal Ethics Committee of Utrecht University and were conducted in agreement with Dutch laws (Wet op de dierproeven, 1996) and European regulations (Guideline 86/609/EEC).

\section{Narrowing Down the QTL and Identification of Candidate Genes}

To narrow down the identified grandparent-dependent QTL for alcohol preference on chromosome 2, which ranged from 112 to $134 \mathrm{Mbp}$ (Lesscher et al., 2009a), haplotype blocks for the A/J and C57BL/6J host strains were identified using the Perlegen Genotype Browser (http://mouse.cs.ucla.edu/perlegen/) within the QTL range. This analysis revealed multiple blocks with genetic variation between A/J and C57BL/6J mice. Subsequently, coding nonsynonymous SNPs within the QTL range, that is, chromosome 2: 112 to $134 \mathrm{Mbp}$, were identified by comparing this genomic region for $\mathrm{A} / \mathrm{J}$ and $\mathrm{C} 57 \mathrm{BL} / 6 \mathrm{~J}$ strains using the Mouse Genome Informatics (MGI) Mouse SNP Query (http://www.informatics.jax.org/javawi2/servlet/ WIFetch?page $=$ snpQF). Finally, to determine which genes are expressed in brain, we aligned the genes within the QTL range with the nearly 20,000 genes with reported brain expression of the Allen Brain Atlas (http://www.brain-map.org/). The remaining candidate genes, identified with this approach, were further explored for their contribution to the observed strain differences in alcohol preference based on brain expression patterns and reported behavioral effects in the literature. For this purpose, we selected genes that were expressed in brain regions that have been associated with reward and addictive behavior, that is, the PFc, AMG, and NAc (using the Allen Brain Atlas). Subsequently, we selected genes for which literature was available to support their role in (reward-related) behavior (http://www.informatics.jax.org). Genes that were involved in other processes, such as platelet regulation, leukemia, inner ear function, and cancer, were excluded at this stage. With this approach, the QTL range was narrowed down to 4 candidate genes: Adal, Chrm5 (muscarinic 5 acetylcholine receptor), Disp2 (Dispatched homolog 2), and Ubr1 (Ubiquitin protein ligase E3 component n-recognin 1).

\section{Expression Analysis of Candidate Genes in Host Strains by Quantitative Polymerase Chain Reaction}

We reasoned that, if genetic variation in the identified candidate genes, that is, Adal, Chrm5, Disp2, and Ubr1 is relevant for the phenotypical difference in alcohol preference between C57BL/6J and CSS-2 mice (Lesscher et al., 2009a), then the expression of these genes in reward-related brain regions would differ between the 2 strains. Therefore, to validate their potential role in regulating alcohol preference, the expression levels of these candidate genes were compared for C57BL/6J and CSS- 2 mice by quantitative polymerase chain reaction (qPCR) analysis. For this purpose, alcoholnaïve mice of both genotypes (CSS-2 and C57BL/6J, $N=6$ ) were sacrificed by rapid decapitation and brains were dissected, snap frozen on dry ice, and stored at $-80^{\circ} \mathrm{C}$. PFc, AMG, and NAc punch samples were obtained using a $20 \mathrm{G}$ punch needle and were immersed instantly in RNAlater (Sigma, Munich, Germany). Total RNA was isolated from these samples using TRIzol (Invitrogen, Bleijswijk, the Netherlands), DNase treated (Ambion, Austin, TX), and purified using the RNeasy MinElute Cleanup kit (Qiagen N.V., Venlo, the Netherlands). Subsequently, cDNA was synthesized from the RNA samples using oligo-dT primers. qPCR analysis was performed using the LightCycler (Roche, Almere, the Netherlands), the Fast Start DNA Master PLUS SYBRgreen I kit (Roche), and primers listed in Table 1. After initial normalization to the housekeeping gene beta-actin, gene expression was calculated as the ratio to levels of $\mathrm{C} 57 \mathrm{BL} / 6 \mathrm{~J}$ mice using the comparative $\mathrm{Ct}$ method (Lesscher et al., 2012; Schmittgen and Livak, 2008).

\section{Limited-Access Ethanol Consumption and Adal Inhibition}

Because Adal, of the 4 identified candidate genes, showed most pronounced and consistent expression differences between CSS-2 and $\mathrm{C} 57 \mathrm{BL} / 6 \mathrm{~J}$ mice, we next assessed the contribution of enhanced Adal levels to the phenotypic difference in alcohol consumption between CSS-2 and C57BL/6J strains. To that aim, the Adal inhibitor erythro-9-(2-hydroxy-3-nonyl)adenine hydrochloride (EHNA; Tocris, Bristol, UK) was used to counteract the augmented Adal activity in CSS-2 mice. Immediately prior to daily alcohol consumption sessions in the limited-access choice paradigm, C57BL/6J and CSS-2 mice were treated with either vehicle (saline) or EHNA (10 $\mathrm{mg} / \mathrm{kg}$ intraperitoneal, $2 \mathrm{ml} / \mathrm{kg}$ in saline) $(N=8$ per strain and treatment). The mice were randomly assigned to the treatment groups (saline or EHNA).

The procedures for ethanol (EtOH) consumption were similar to those used previously (Lesscher et al., 2009a, 2012). A limitedaccess paradigm using a $15 \%$ EtOH solution was employed. In line with this paradigm, mice readily consume high amounts of alcohol and show a gradual increase in alcohol consumption over the course of 2 to 4 weeks (Lesscher et al., 2009b, 2012). Moreover, using a limited-access paradigm with $20 \%$ alcohol, strain differences in alcohol consumption in mice have been demonstrated, including reduced alcohol intake in $\mathrm{A} / \mathrm{J}$ compared to $\mathrm{C} 57 \mathrm{BL} / 6 \mathrm{~J}$ mice (Rhodes et al., 2007). Importantly, reduced alcohol consumption by $\mathrm{A} / \mathrm{J}$ mice compared to $\mathrm{C} 57 \mathrm{BL} / 6 \mathrm{~J}$ mice is not dependent on the alcohol concentration nor to limited access to alcohol. For example, a study by Yoneyama and colleagues (2008) showed that A/J mice consumed less alcohol compared to $\mathrm{C} 57 \mathrm{BL} / 6 \mathrm{~J}$ mice in a continuousaccess 2-bottle choice task using 3, 6, and 10\% alcohol.

The mice were placed in a separate test cage for 2 hours starting at 10:00 AM daily for 3 consecutive weeks. The mice received access to 2 drinking tubes, that is, $10-\mathrm{ml}$ polystyrene pipettes fitted with a stainless steel ball-bearing sipper tube. One tube delivered tap water

Table 1. Primer Sequences for qPCR Validation of Candidate Genes

\begin{tabular}{lc}
\hline Primer Fwd & \multicolumn{1}{c}{ Primer Rev } \\
\hline TTCTTGGCCTTGACCTCAGT & CAGAGGCGCTAAGGAATGTC \\
TCAGCCATCAAATGACCAAA & AGTAACCCAAGTGCCACAGG \\
CTGGCCTTCATCTTCCTCTG & GGAGGCTTGAGCTGTTCATC \\
ACTCCGTGGTTATGGCTCAC & AGGATCTTACGGGCACCTTT \\
\hline
\end{tabular}


and the other $15 \% \mathrm{EtOH}(\mathrm{v} / \mathrm{v}$ in tap water). During the initial 7 days of training, the water and $\mathrm{EtOH}$ bottles were on fixed locations. Thereafter, the bottle positions were switched daily to avoid side preference. Fluid volumes were measured to the nearest $0.05 \mathrm{ml}$ prior to and after each drinking session, by reading the pipette scale. Alcohol consumption was monitored during 3 consecutive weeks, and average $\mathrm{EtOH}$ intake $(\mathrm{g} / \mathrm{kg}), \mathrm{EtOH}$ preference $(\%$ of total fluid intake), and total fluid consumption $(\mathrm{ml} / \mathrm{kg})$ per week were calculated and compared between strains and treatment groups.

\section{Statistical Analysis}

SPSS 22.0 (Windows; IBM Corp., Armonk, NY) was used for statistical analyses. qPCR data were analyzed per brain region (AMG, PFc, NAc) using multivariate analyses of variance (ANOVAs), with genotype as the between-subjects factor. EtOH consumption data were analyzed by 3-way repeated-measures ANOVAs with genotype and treatment as the between-subjects factor and time as the repeated-measures within-subjects factor. Post hoc analysis was performed by $t$-tests where appropriate. Differences between pairs of means were considered significant at $\alpha<0.05$. All results are shown as mean \pm SEM values.

\section{RESULTS}

\section{Identification of Candidate Genes}

To narrow down the previously identified QTL for alcohol preference on mouse chromosome 2, we first identified, using the MGI Gene Query, a total of 369 protein-coding genes within the QTL range (112 to $134 \mathrm{Mbp}$ ). Subsequently, haplotype mapping was performed using the Perlegen Genotype Browser to compare the haplotype blocks for the C57BL/6J and $\mathrm{A} / \mathrm{J}$ host strains within the QTL range (112 to $134 \mathrm{Mbp}$ ). With this approach, the QTL range was reduced to 20 blocks with genetic variation between $\mathrm{C} 57 \mathrm{BL} / 6 \mathrm{~J}$ and
A/J mice, leaving 168 candidate genes (Fig. 1). Thereafter, coding nonsynonymous SNPs within the QTL range were identified using the MGI Mouse SNP Query, which resulted in a further reduction of the number of candidate genes to 52. Finally, we determined which genes within the QTL are expressed in brain tissue and may constitute part of the neuromolecular mechanism that controls alcohol consumption. The list of candidate genes was aligned with the nearly 20,000 genes expressed in the brain in accordance to Allen Brain Atlas (http://www.brain-map.org/). This reduced the list of candidate genes to a total of 43 genes (Table 2).

To further narrow down the list of remaining candidate genes, the expression patterns of the remaining 43 genes were explored, thereby focusing on brain regions that have been associated with reward and addictive behavior, that is, the PFc, AMG, and NAc. For the majority of genes that remained based on their brain expression pattern (20 genes), there was no evidence for involvement in the modulation of behavior (http:// www.informatics.jax.org). These genes were, for example, implicated in platelet regulation, leukemia, inner ear function, and cancer. These genes were therefore discarded from our candidate gene list, leaving us with 4 genes that are expressed in reward-related brain regions (PFc, $\mathrm{AMG}$, and $\mathrm{NAc}$ ) and have been implicated, directly or indirectly, in (reward-related) behavior, that is, Adal (Golembiowska and Zylewska, 2000), Chrm5 (Basile et al., 2002; Thomsen et al., 2005), Disp2 (Galli et al., 2014), and Ubr1 (Balogh et al., 2002).

\section{Enhanced Adal and Chrm5 Expression in Brains of CSS-2 Mice}

To assess whether Adal, Chrm5, Disp2, and Ubr1 are involved in alcohol preference, mRNA expression levels for

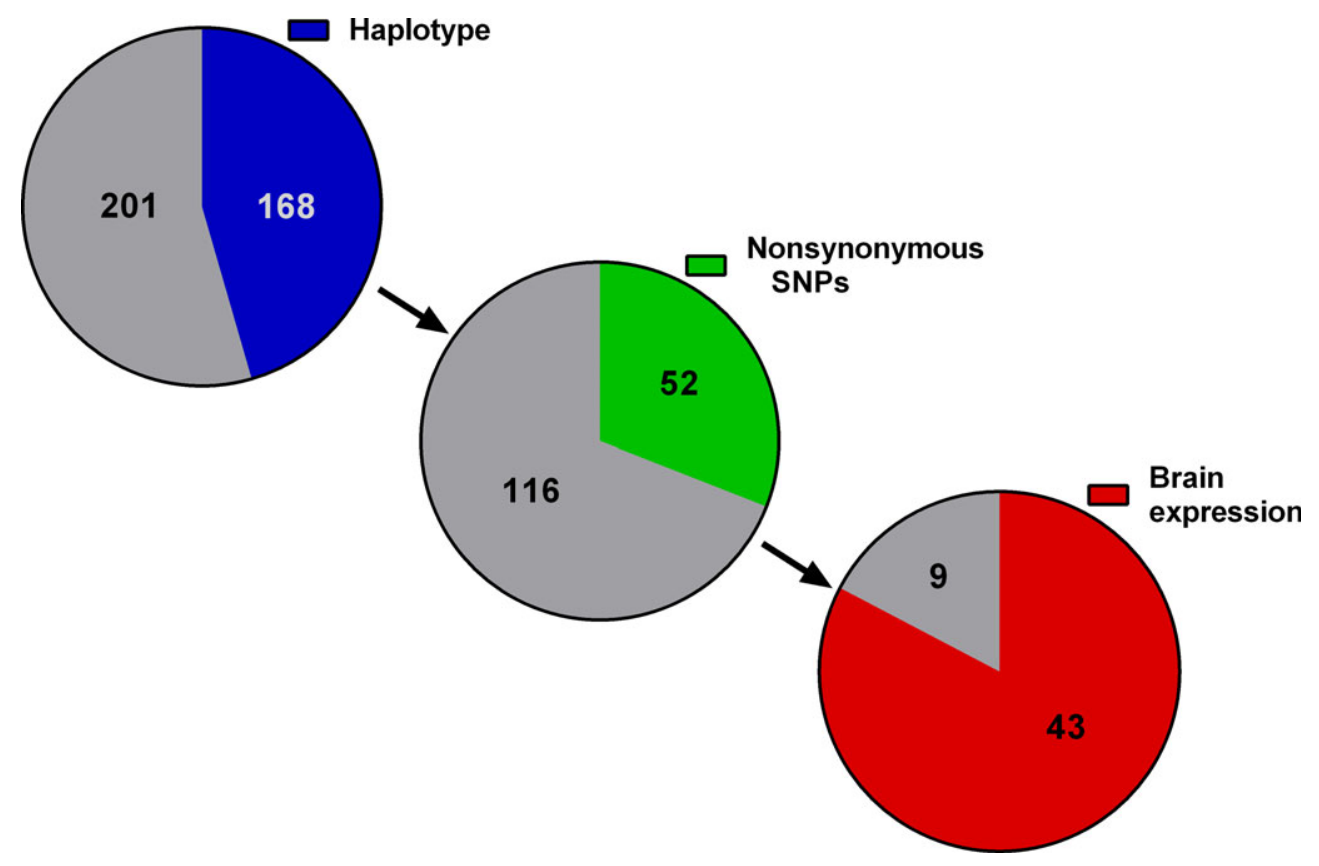

Fig. 1. The quantitative trait loci on mouse chromosome 2 for alcohol preference comprised a total of 369 genes. This number was reduced to 43 candidate genes through haplotype mapping, in silico SNP analysis and selection for brain expression. 
Table 2. Candidate Genes Identified in the Alcohol Preference Quantitative Trait Locus on Mouse Chromosome 2

\begin{tabular}{|c|c|}
\hline Adal & Adenosine deaminase-like \\
\hline Ap4e1 & Adaptor-related protein complex AP-4, epsilon 1 \\
\hline Arhgap11a & Rho GTPase-activating protein $11 \mathrm{~A}$ \\
\hline B2m & Beta-2 microglobulin \\
\hline Blvra & Biliverdin reductase $\mathrm{A}$ \\
\hline Bub1b & $\begin{array}{l}\text { Budding uninhibited by benzimidazoles } \\
1 \text { homolog, beta (Saccharomyces cerevisiae) }\end{array}$ \\
\hline Casc5 & Cancer susceptibility candidate 5 \\
\hline Catsper2 & Cation channel, sperm associated 2 \\
\hline Ccndbp1 & Cyclin D-type binding protein 1 \\
\hline Cdan1 & Congenital dyserythropoietic anemia, type I (human) \\
\hline Chac1 & ChaC, cation transport regulator-like 1 (Escherichia colt) \\
\hline Chrm5 & Cholinergic receptor, muscarinic 5 \\
\hline Ctdspl2 & $\begin{array}{l}\text { CTD (carboxy-terminal domain, RNA polymerase II, } \\
\text { polypeptide A) small phosphatase like } 2\end{array}$ \\
\hline Disp2 & Dispatched homolog 2 (Drosophila) \\
\hline DIl4 & Delta-like 4 (Drosophila) \\
\hline Dnajc17 & DnaJ (Hsp40) homolog, subfamily C, member 17 \\
\hline Duoxa1 & Dual oxidase maturation factor 1 \\
\hline Epb4.2 & Erythrocyte protein band 4.2 \\
\hline Fsip1 & Fibrous sheath-interacting protein 1 \\
\hline Hisppd2a & Histidine acid phosphatase domain containing $2 \mathrm{~A}$ \\
\hline Itpka & Inositol 1,4,5-trisphosphate 3-kinase A \\
\hline Lcmt2 & Leucine carboxyl methyltransferase 2 \\
\hline Ltk & Leukocyte tyrosine kinase \\
\hline Mapkbp1 & Mitogen-activated protein kinase binding protein 1 \\
\hline Mga & MAX gene associated \\
\hline Mtap1a & Microtubule-associated protein $1 \mathrm{~A}$ \\
\hline Ndufaf1 & $\begin{array}{l}\text { NADH dehydrogenase (ubiquinone) } 1 \text { alpha } \\
\text { subcomplex, assembly factor } 1\end{array}$ \\
\hline Nusap1 & Nucleolar and spindle-associated protein 1 \\
\hline Pak6 & p21 (CDKN1A)-activated kinase 6 \\
\hline Pla2g4b & Phospholipase A2, group IVB (cytosolic) \\
\hline Plcb2 & Phospholipase C, beta 2 \\
\hline Pldn & Pallidin \\
\hline Rpap1 & RNA polymerase II-associated protein 1 \\
\hline Slc30a4 & Solute carrier family 30 (zinc transporter), member 4 \\
\hline Strc & Stereocilin \\
\hline Trp53bp1 & Transformation-related protein 53 binding protein 1 \\
\hline Ubr1 & Ubiquitin protein ligase E3 component $n$-recognin 1 \\
\hline Zfyve19 & Zinc finger, FYVE domain containing 19 \\
\hline 2310003F16Rik & RIKEN CDNA $2310003 F 16$ gene \\
\hline 6330405D24Rik & RIKEN cDNA 6330405D24 gene \\
\hline A430105l19Rik & RIKEN cDNA A430105I19 gene \\
\hline A530010F05Rik & RIKEN cDNA A530010F05 gene \\
\hline A530057A03Rik & RIKEN cDNA A530057A03 gene \\
\hline
\end{tabular}

these genes were compared in $\mathrm{PFc}, \mathrm{AMG}$, and NAc of CSS-2 and C57BL/6J mice. Analysis of the data revealed an up-regulation of Adal in CSS-2 versus C57BL/6J mice in all 3 brain regions: $\mathrm{PFc}, F_{\text {genotype }}(1,11)=30.4$, $p<0.001$, AMG $F_{\text {genotype }}(1,11)=5.7, p<0.05$, and NAc, $F_{\text {genotype }}(1,11)=7.4, p<0.05$ (Fig. 2). Ubr1 was up-regulated in the AMG of CSS-2 mice, $F_{\text {genotype }}(1,11)=7.2$, $p<0.05$, while Chrm5 levels were increased in the PFc of the CSS-2 strain, $F_{\text {genotype }}(1,11)=5.3, p<0.05$. Collectively, these data provide evidence for involvement of 3 of

Fig. 2. qPCR analysis comparing Adal, Chrm5, Disp2, and Ubr1 expression between strains. There was an up-regulation of Adal in CSS-2 versus C57BL/6J mice in PFC (A), AMG (B), and NAc (C). In addition, Ubr1 mRNA levels were increased in CSS-2 in AMG and Chrm5 mRNA levels were higher in PFC of CSS-2 versus C57BL/6J mice. Shown are mean \pm SEM. $* p<0.05, * * p<0.01$.

\section{A}

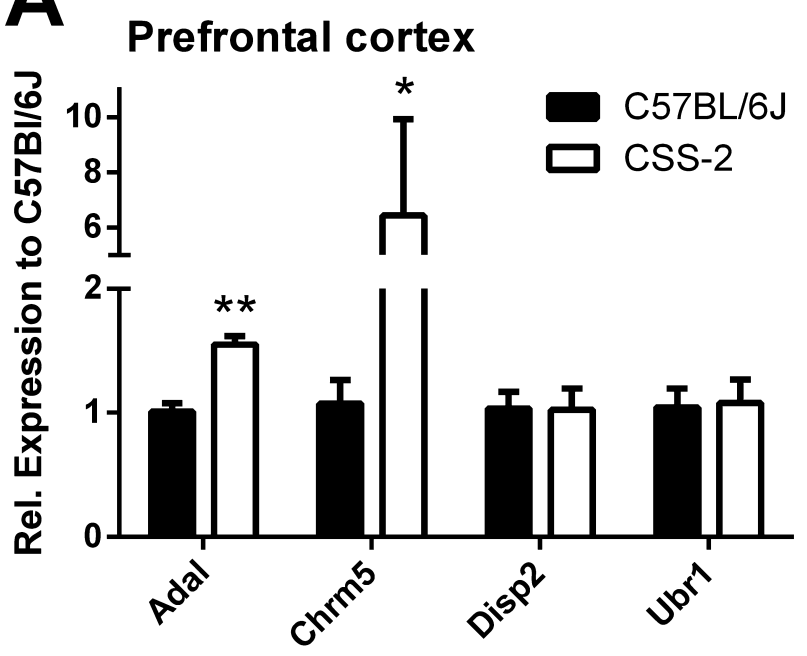

B

\section{Amygdala}
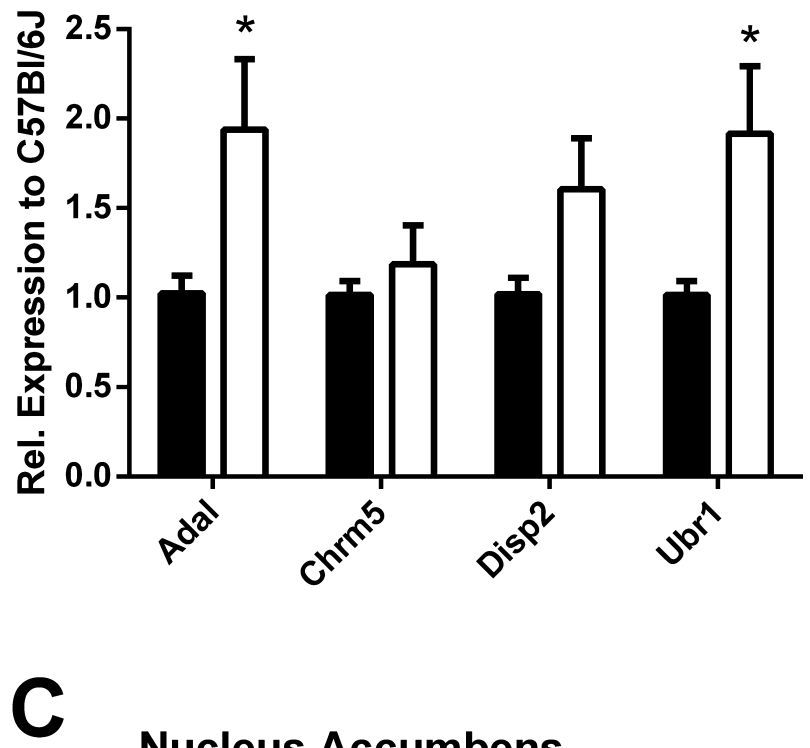

Nucleus Accumbens

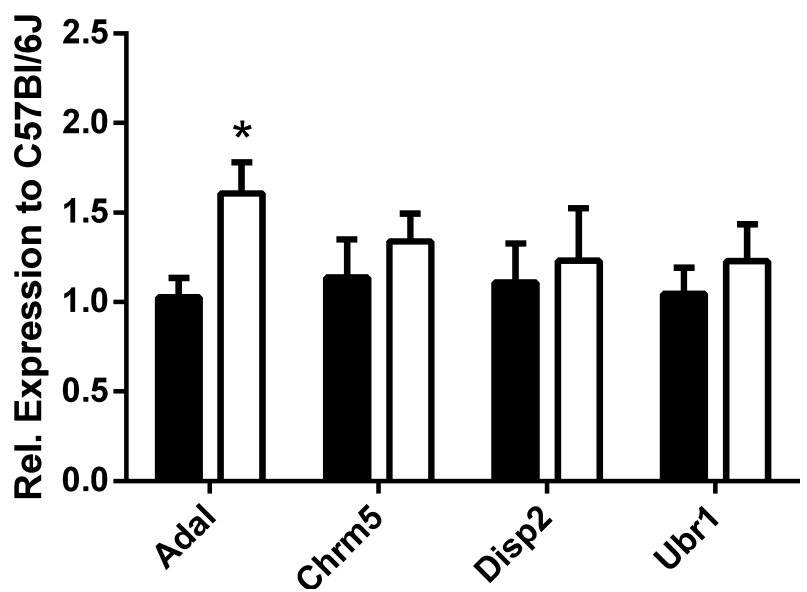


the identified candidate genes, in the phenotypic differences in alcohol consumption and preference between CSS-2 and C57BL/6J mice.

\section{Reversal of the CSS-2 Alcohol Preference Phenotype by Adal Inhibition}

As of the 4 candidate genes, Adal was up-regulated in all regions examined (i.e., PFc, AMG, and NAc) of CSS-2 mice, we next explored the functional role of Adal in regulating alcohol consumption in CSS-2 mice. For that purpose, we used the adenosine deaminase inhibitor EHNA (Nelson et al., 2009; Rosemberg et al., 2007; Woodson et al., 1998), to counteract the putatively increased adenosine deaminase activity in CSS-2 mice. Animals of both strains were treated with either vehicle or EHNA prior to each daily alcohol consumption session. Alcohol intake increased over time, $F_{\text {time }}(2,54)=29.9, p<0.001$, indicative of escalation of alcohol intake as we have reported previously (Lesscher et al., 2009a, 2012). In agreement with previous findings, the CSS-2 mice showed lower levels of alcohol intake, $F_{\text {genotype }}(1, \quad 27)=29.5, \quad p<0.001, \quad F_{\text {time }} \times$ genotype $(2$, $54)=18.2, p<0.001$, and lower alcohol preference when compared to $\mathrm{C} 57 \mathrm{BL} / 6 \mathrm{~J}$ mice, $F_{\text {genotype }}(1,27)=53.4$, $p<0.001$, independent of time, $F_{\text {time }} \times$ genotype $(2,54)=2.6$, N.S. (Fig. 3; Lesscher et al., 2009a). There were no genotype differences in the total amount of fluid consumed, $F_{\text {genotype }}(1$, $27)=0.48$, N.S., $F_{\text {time }} \times$ genotype $(2,54)=0.32$, N.S.

Analysis of the effects of EHNA treatment revealed a selective increase in alcohol preference in CSS-2 mice, partly reversing their preference phenotype to that of the $\mathrm{C} 57 \mathrm{BL} / 6 \mathrm{~J}$ host strain (Fig. 3). There was no overall effect of EHNA on alcohol preference, $F_{\text {treatment }}(1,27)=1.3$, N.S. However, treatment with EHNA altered alcohol preference in a genotype-dependent manner, $F_{\text {genotype } \times \text { treatment }}(1,27)=5.9$, $p<0.05$. Post hoc pairwise comparisons confirmed that EHNA increased alcohol preference in CSS-2 mice $(p=0.019)$ but did not affect alcohol preference in C57BL/ $6 \mathrm{~J}$ mice $(p=0.366)$, supporting the functional contribution of Adal to the low alcohol preference phenotype of CSS-2 mice. Post hoc pairwise comparisons by week revealed that EHNA increased alcohol preference in CSS-2 mice predominantly in weeks 2 and 3 of the experiment (wk1: $p=0.066$; wk2: $p=0.024 ;$ wk3: $p=0.043$ ). Although EHNA increased alcohol preference in CSS-2 mice, the Adal inhibitor did not alter alcohol intake: there was no overall effect of treatment on alcohol intake, $F_{\text {treatment }}(1,27)=0.17$, N.S., nor was there a genotype-dependent effect of this compound on alcohol intake, $F_{\text {genotype } \times \text { treatment }}(2,54)=0.3$, N.S. Importantly, EHNA did not affect total fluid consumption, $F_{\text {treatment }}(1,26)=0.06$, N.S., $F_{\text {genotype } \times \text { treatment }}(1,26)=1.4$, N.S., ruling out aspecific effects on thirst or fluid ingestion.
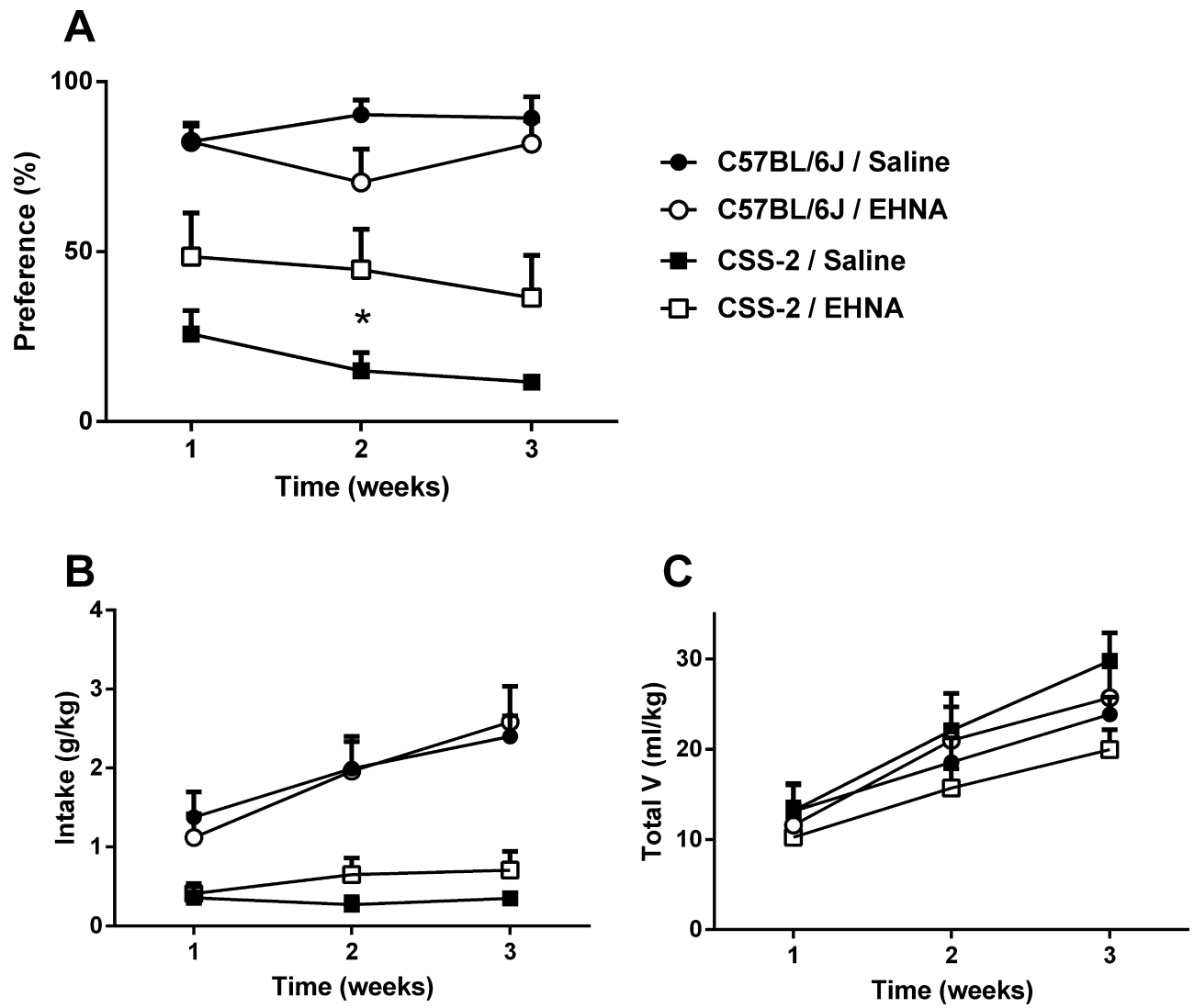

Fig. 3. Adal inhibition by systemic administration of EHNA partly reversed the low alcohol preference phenotype of CSS-2 mice without affecting alcohol preference in C57BL/6J mice (A) or alcohol intake (B) and total fluid consumption (C). Shown are mean \pm SEM. ${ }^{*} p<0.05$. 
Moreover, there were no differences in body weight across the experiment for the genotypes or treatment groups, $F_{\text {genotype }}(1,27)=0.46$, N.S., $F_{\text {time } \times \text { genotype }}(2,54)=2.1$, N.S., $\quad F_{\text {treatment }}(1,27)=0.17, \quad$ N.S., $F_{\text {genotype }} \times$ treatment $(1$, $27)=1.8$, N.S. (data not shown).

\section{DISCUSSION}

This study identifies Adal as an important candidate gene within a QTL for alcohol preference on mouse chromosome 2. Compared to $\mathrm{C} 57 \mathrm{BL} / 6 \mathrm{~J}$ mice, Adal expression was enhanced in reward-related brain regions in the low alcohol preferring CSS-2 strain, and inhibition of Adal activity selectively increased alcohol preference in CSS-2 mice.

\section{Candidate Genes Identified Within the Alcohol Preference $Q T L$}

To identify candidate genes within the alcohol preference QTL, we applied criteria that have previously been used to distinguish candidate genes within a QTL: coding SNPs, gene expression patterns, and gene function (Korstanje and Paigen, 2002; Nikolskiy et al., 2015; Noyes et al., 2011). A limitation of this approach is that potentially relevant genes are excluded because noncoding SNPs or other brain regions may also contribute to alcohol preference. Moreover, using this approach, only genes with a known function, that is, based on available literature were selected, thus ruling out potential novel candidate genes. The previously identified QTL for alcohol preference was narrowed down to 4 candidate genes that have, directly or indirectly, been implicated in the modulation of reward sensitivity, that is, Adal, Chrm5, Disp2, and Ubr1. Adal belongs to the adenosine deaminase (Ada) family, based on phylogenetic analyses (Maier et al., 2005; Rosemberg et al., 2007). EtOH has been shown to inhibit Ada activity in rat forebrain (Sogut and Kanbak, 2010), and Ada inhibition reduced methamphetamineinduced dopamine release and stereotypy (Golembiowska and Zylewska, 2000). Chrm5 knockout mice show reduced morphine-induced conditioned place preference and cocaine self-administration (Basile et al., 2002; Thomsen et al., 2005) and altered amphetamine- and morphine-induced NAc dopamine release (Schmidt et al., 2010). Disp2 is involved in hedgehog signaling that affects transcription of Wnt genes, which in turn are important for the development and maintenance of mesolimbic dopamine neurons and contribute to amphetamine-induced activity (Galli et al., 2014; Wurst and Prakash, 2014). Finally, Ubr 1 null mice show reduced motor activity and impaired spatial learning (Balogh et al., 2002) that may also have implications for reward learning and substance addiction.

Differential expression of these genes between CSS-2 and C57BL/6J mice suggests that they contribute to the alcohol phenotype of CSS-2 mice, that is, reduced alcohol consumption and preference compared to C57BL/6J mice (Lesscher et al., 2009a). Therefore, expression levels of Adal, Chrm5,
Disp2, and Ubr1 were compared in brain regions that contribute to reward and addiction, that is, $\mathrm{PFc}, \mathrm{AMG}$, and NAc (Everitt and Robbins, 2013; Koob and Volkow, 2010; Tabakoff and Hoffman, 2013). We found that Adal expression was increased in all 3 regions in CSS- 2 mice. In addition, the expression of Ubr1 and Chrm5 was increased in the AMG and PFc of CSS-2 mice, respectively.

\section{Adenosine and Alcohol Consumption}

Adal belongs to the Ada family (Maier et al., 2005; Rosemberg et al., 2007). Adenosine deaminases are known to cleave, through deamination, adenosine into inosine, thereby reducing adenosine levels, although physiological evidence to confirm that Adal converts adenosine to inosine, as Ada does, is at present lacking. Mice of the CSS-2 strain showed enhanced expression of Adal in PFc, AMG, and NAc. Enhanced Adal expression in CSS-2 mice therefore likely results in lower brain adenosine levels, which is associated with lower alcohol preference. Conversely, alcohol itself has been shown to inhibit Ada activity in rat forebrain (Sogut and Kanbak, 2010), which results in increased brain adenosine levels. Together, this suggests that increased forebrain adenosine activity stimulates alcohol intake. Indeed, inhibition of Ada using EHNA, thereby increasing adenosine levels, partially reversed the low alcohol preference phenotype of CSS-2 mice. In contrast, EHNA did not affect alcohol intake or preference in C57BL/ $6 \mathrm{~J}$ mice, suggesting that a further increase in adenosine activity above baseline levels does not alter the effects of alcohol in this strain. Although we did not measure blood alcohol levels after the drinking sessions, the blood alcohol levels for CSS-2 mice are likely to be low. Thus, the question remains whether Adal influences the pharmacological effects of alcohol, or perhaps its rewarding or aversive effects. However, taste is not likely to account for the observed strain difference, and, hence, the effects of EHNA on alcohol preference, because previous studies did not reveal differences in taste sensitivity between CSS-2 and C57BL/6J mice (Lesscher et al., 2009a). Together, these findings show that adenosine levels may determine the risk for or resilience to alcohol consumption and, ultimately, AUD.

The present findings somewhat contrast with previous work on adenosine signaling and alcohol consumption; that is, adenosine $2 \mathrm{~A}(\mathrm{~A} 2 \mathrm{~A})$ receptor null mutant mice show enhanced alcohol consumption (Houchi et al., 2008; Naassila et al., 2002) while treatment with an A2A agonist reduced alcohol intake (Houchi et al., 2013). In addition, alcohol consumption is enhanced in null mutants of one of the major transporters of adenosine in the brain, type 1 equilibrative nucleoside transporter (ENT) (e.g., Choi et al., 2004). There are several possible explanations for these seemingly discrepant findings. First, the increased sensitivity to alcohol reward in $\mathrm{A} 2 \mathrm{~A}$ null mice depends on the genetic background; it is only apparent on a CD1, but not a C57BL/ $6 \mathrm{~J}$ background (Houchi et al., 2008). Second, because ENT is a bidirectional adenosine transporter, the adenosine 
dynamics of ENT knockout mice is very much different from CSS-2 mice, with presumably lower circulating adenosine. Third, an important difference with the studies by Houchi and colleagues (2008) and Naassila and colleagues (2002) is that we restricted access to alcohol to 2 hours each day, as opposed to using a 24-hour 2-bottle choice paradigm. We report selective effects of genotype (C57BL/6J vs. CSS-2) and EHNA on alcohol preference using this limited-access paradigm. These findings agree with the selectivity of the previously identified QTL for alcohol preference (Lesscher et al., 2009a), suggesting that there is a genetic and neurobiological dissociation of alcohol preference and alcohol intake. Limited-access paradigms result in higher levels of alcohol intake, but also in a clear preference for alcohol (e.g., Lesscher et al., 2009a, 2012), which is often not evident when mice have continuous access to alcohol in 24-hour 2-bottle choice tasks (e.g., Gill and Boyle, 2005; Hodge et al., 1999; Nie et al., 2011; Peirce et al., 1998; Tarantino et al., 1998). Our current findings suggest that when access to alcohol is restricted, adenosine signaling may selectively alter alcohol preference. Indeed, A2A knockout mice also show a selective increase in alcohol preference in the limited-access paradigm while consuming similar levels of alcohol (H.M.B. Lesscher and A. Bailey, unpublished). Taken together, the current findings confirm the importance of adenosine signaling for alcohol drinking, although the precise mechanisms require further study.

Actual adenosine levels, but also the dynamics of adenosine signaling, may impact on behavior. Diurnal fluctuations in adenosine levels - low during sleep time while rising during wake time- have been proposed to contribute to day-night cycling (Porkka-Heiskanen et al., 1997). Importantly, daynight cycling is a key factor in alcohol consumption by rodents. Limited-access paradigms (Lesscher et al., 2009a, 2012; Rhodes et al., 2005) employ the natural tendency of rodents to consume most of their fluids during the active phase, providing access to alcohol in the beginning of the dark cycle, when they consume most of their fluids (Dole and Gentry, 1984). It is therefore conceivable that altered adenosine dynamics may, by altering the sleep-wake cycle, lead to the reduced alcohol preference alcohol observed in CSS-2 mice.

\section{Neurobiological Mechanisms of Adenosine Modulation of Alcohol Reward}

Adenosine acts as a modulator of neurotransmission in the central nervous system, which may influence a variety of behaviors, including addictive behavior (Burnstock et al., 2011). The effects of adenosine in the central nervous system are mediated through adenosine $\mathrm{A} 1$ and $\mathrm{A} 2$ receptors, the latter of which has been implicated in drug taking (Arolfo et al., 2004; Houchi et al., 2008; Naassila et al., 2002; Thorsell et al., 2007). These adenosine receptors have been shown to interact with multiple receptor types, which allows adenosine to impact on a wide array of neurobiological systems and behaviors. For example, A2A receptors interact with dopamine D1 and D2 receptors, but also with A1 receptors and metabotropic glutamate receptors (e.g., Nam et al., 2013; Sebastiao and Ribeiro, 2000), all of which have been implicated in addictive behavior (Dalley and Everitt, 2009; Fuxe et al., 2010; Hack and Christie, 2003; Pomierny-Chamiolo et al., 2014). Indeed, $\mathrm{A} 2 \mathrm{~A}$ and D2 receptors have been shown to synergistically regulate alcohol consumption (Yao et al., 2002).

The elevation in Adal levels in CSS-2 mice versus C57BL/ $6 \mathrm{~J}$ mice was observed in the PFc, AMG, and NAc. These brain regions have been implicated in the transition to excessive alcohol use, which is a critical determinant of alcoholism (Darcq et al., 2015; George et al., 2012). The AMG, and in particular its central nucleus (CeA), is known to contribute to dependence-induced drinking (e.g., Funk et al., 2006; Gilpin et al., 2008; Pandey et al., 2008). Moreover, the CeA contributes to escalation of alcohol intake and the development of quinine-resistant alcohol consumption (e.g., Lesscher et al., 2012). Finally, there is a substantial body of evidence implicating the NAc in alcohol consumption (e.g., Cozzoli et al., 2012; Griffin et al., 2014; Hopf et al., 2011; Neasta et al., 2011). Thus, the observed up-regulation of Adal in CSS- 2 mice in these brain regions likely contributes to the low alcohol preference of these animals.

\section{CONCLUSION}

This study identified Adal as a genetically protective factor against alcohol preference drinking in mice, where elevated Adal levels contribute to low levels of alcohol intake. An intriguing question that remains to be addressed is whether, conversely, adenosine deaminase deficiencies increase an individuals' propensity to consume alcohol. This is conceivable, as high alcohol drinking $\mathrm{C} 57 \mathrm{BL} / 6 \mathrm{~J}$ mice (Rhodes et al., 2007) are considered to be a rodent model for AUD (for review, see Hopf and Lesscher, 2014). Ada replacement therapies are used clinically, and these have, for example, been used to successfully treat immune deficient patients, who suffer from Ada insufficiency (Brigida et al., 2014; Grunebaum et al., 2013). Ada replacement may therefore represent a strategy to treat AUD and perhaps other forms of addiction. Future studies, using clinically relevant models for AUD (Hopf et al., 2010; Lesscher et al., 2010; Seif et al., 2015; Spoelder et al., 2015; Vanderschuren et al., 2017), should investigate this possibility.

\section{FUNDING AND DISCLOSURE}

This study was supported by a Fellowship from the Brain Foundation of the Netherlands, grant H06.08 to HMBL. The authors declare no conflict of interest.

\section{REFERENCES}

Abiola O, Angel JM, Avner P, Bachmanov AA, Belknap JK, Bennett B, Blankenhorn EP, Blizard DA, Bolivar V, Brockmann GA, Buck KJ, Bureau JF, Casley WL, Chesler EJ, Cheverud JM, Churchill GA, Cook 
M, Crabbe JC, Crusio WE, Darvasi A, de Haan G, Dermant P, Doerge RW, Elliot RW, Farber CR, Flaherty L, Flint J, Gershenfeld H, Gibson JP, Gu J, Gu W, Himmelbauer H, Hitzemann R, Hsu HC, Hunter K, Iraqi FF, Jansen RC, Johnson TE, Jones BC, Kempermann G, Lammert F, Lu L, Manly KF, Matthews DB, Medrano JF, Mehrabian M, Mittlemann G, Mock BA, Mogil JS, Montagutelli X, Morahan G, Mountz JD, Nagase H, Nowakowski RS, O'Hara BF, Osadchuk AV, Paigen B, Palmer AA, Peirce JL, Pomp D, Rosemann M, Rosen GD, Schalkwyk LC, Seltzer Z, Settle S, Shimomura K, Shou S, Sikela JM, Siracusa LD, Spearow JL, Teuscher C, Threadgill DW, Toth LA, Toye AA, Vadasz C, Van Zant G, Wakeland E, Williams RW, Zhang HG, Zou F; Complex Trait Consortium (2003) The nature and identification of quantitative trait loci: a community's view. Nat Rev Genet 4:911-916.

Arolfo MP, Yao L, Gordon AS, Diamond I, Janak PH (2004) Ethanol operant self-administration in rats is regulated by adenosine A2 receptors. Alcohol Clin Exp Res 28:1308-1316.

Balogh SA, McDowell CS, Denenberg VH (2002) Behavioral characterization of mice lacking the ubiquitin ligase UBR1 of the N-end rule pathway. Genes Brain Behav 1:223-229.

Basile AS, Fedorova I, Zapata A, Liu X, Shippenberg T, Duttaroy A, Yamada M, Wess J (2002) Deletion of the M5 muscarinic acetylcholine receptor attenuates morphine reinforcement and withdrawal but not morphine analgesia. Proc Natl Acad Sci U S A 99:11452-11457.

Brigida I, Sauer AV, Ferrua F, Giannelli S, Scaramuzza S, Pistoia V, Castiello MC, Barendregt BH, Cicalese MP, Casiraghi M, Brombin C, Puck J, Muller K, Notarangelo LD, Montin D, van Montfrans JM, Roncarolo MG, Traggiai E, van Dongen JJ, van der Burg M, Aiuti A (2014) B-cell development and functions and therapeutic options in adenosine deaminase-deficient patients. J Allergy Clin Immunol 133:799-806.e10.

Bubier JA, Jay JJ, Baker CL, Bergeson SE, Ohno H, Metten P, Crabbe JC, Chesler EJ (2014) Identification of a QTL in Mus musculus for alcohol preference, withdrawal, and $\mathrm{Ap} 3 \mathrm{~m} 2$ expression using integrative functional genomics and precision genetics. Genetics 197:1377-1393.

Burnstock G, Krugel U, Abbracchio MP, Illes P (2011) Purinergic signalling: from normal behaviour to pathological brain function. Prog Neurobiol 95:229-274.

Choi DS, Cascini MG, Mailliard W, Young H, Paredes P, McMahon T, Diamond I, Bonci A, Messing RO (2004) The type 1 equilibrative nucleoside transporter regulates ethanol intoxication and preference. Nat Neurosci 7:855-861.

Cozzoli DK, Courson J, Caruana AL, Miller BW, Greentree DI, Thompson $\mathrm{AB}$, Wroten MG, Zhang PW, Xiao B, Hu JH, Klugmann M, Metten P, Worley PF, Crabbe JC, Szumlinski KK (2012) Nucleus accumbens mGluR5-associated signaling regulates binge alcohol drinking under drinking-in-the-dark procedures. Alcohol Clin Exp Res 36:1623-1633.

Dalley JW, Everitt BJ (2009) Dopamine receptors in the learning, memory and drug reward circuitry. Semin Cell Dev Biol 20:403-410.

Darcq E, Warnault V, Phamluong K, Besserer GM, Liu F, Ron D (2015) MicroRNA-30a-5p in the prefrontal cortex controls the transition from moderate to excessive alcohol consumption. Mol 20:1219-1231.

Dole VP, Gentry RT (1984) Toward an analogue of alcoholism in mice: scale factors in the model. Proc Natl Acad Sci U S A 81:3543-3546.

Everitt BJ, Robbins TW (2013) From the ventral to the dorsal striatum: devolving views of their roles in drug addiction. Neurosci Biobehav Rev 37:1946-1954.

Funk CK, O'Dell LE, Crawford EF, Koob GF (2006) Corticotropin-releasing factor within the central nucleus of the amygdala mediates enhanced ethanol self-administration in withdrawn, ethanol-dependent rats. J Neurosci 26:11324-11332.

Fuxe K, Marcellino D, Borroto-Escuela DO, Guescini M, FernandezDuenas V, Tanganelli S, Rivera A, Ciruela F, Agnati LF (2010) Adenosine-dopamine interactions in the pathophysiology and treatment of CNS disorders. CNS Neurosci Ther 16:e18-e42.

Galli S, Lopes DM, Ammari R, Kopra J, Millar SE, Gibb A, Salinas PC (2014) Deficient Wnt signalling triggers striatal synaptic degeneration and impaired motor behaviour in adult mice. Nat Commun 5:4992.
George O, Sanders C, Freiling J, Grigoryan E, Vu S, Allen CD, Crawford E, Mandyam CD, Koob GF (2012) Recruitment of medial prefrontal cortex neurons during alcohol withdrawal predicts cognitive impairment and excessive alcohol drinking. Proc Natl Acad Sci U S A 109:18156-18161.

Gill K, Boyle AE (2005) Genetic analysis of alcohol intake in recombinant inbred and congenic strains derived from $\mathrm{A} / \mathrm{J}$ and $\mathrm{C} 57 \mathrm{BL} / 6 \mathrm{~J}$ progenitors. Mamm Genome 16:319-331.

Gilpin NW, Misra K, Koob GF (2008) Neuropeptide Y in the central nucleus of the amygdala suppresses dependence-induced increases in alcohol drinking. Pharmacol Biochem Behav 90:475-480.

Golembiowska K, Zylewska A (2000) Effect of adenosine kinase, adenosine deaminase and transport inhibitors on striatal dopamine and stereotypy after methamphetamine administration. Neuropharmacology 39:2124 2132.

Griffin WC 3rd, Haun HL, Hazelbaker CL, Ramachandra VS, Becker HC (2014) Increased extracellular glutamate in the nucleus accumbens promotes excessive ethanol drinking in ethanol dependent mice. Neuropsychopharmacology 39:707-717.

Grunebaum E, Cohen A, Roifman CM (2013) Recent advances in understanding and managing adenosine deaminase and purine nucleoside phosphorylase deficiencies. Curr Opin Allergy Clin Immunol 13:630-638.

Hack SP, Christie MJ (2003) Adaptations in adenosine signaling in drug dependence: therapeutic implications. Crit Rev Neurobiol 15:235-274.

Hodge CW, Mehmert KK, Kelley SP, McMahon T, Haywood A, Olive MF, Wang D, Sanchez-Perez AM, Messing RO (1999) Supersensitivity to allosteric GABA(A) receptor modulators and alcohol in mice lacking PKCepsilon. Nat Neurosci 2:997-1002.

Hopf FW, Chang SJ, Sparta DR, Bowers MS, Bonci A (2010) Motivation for alcohol becomes resistant to quinine adulteration after 3 to 4 months of intermittent alcohol self-administration. Alcohol Clin Exp Res 34:15651573 .

Hopf FW, Lesscher HMB (2014) Rodent models for compulsive alcohol intake. Alcohol 48:253-264.

Hopf FW, Simms JA, Chang SJ, Seif T, Bartlett SE, Bonci A (2011) Chlorzoxazone, an SK-type potassium channel activator used in humans, reduces excessive alcohol intake in rats. Biol Psychiatry 69: 618-624.

Houchi H, Persyn W, Legastelois R, Naassila M (2013) The adenosine A2A receptor agonist CGS 21680 decreases ethanol self-administration in both non-dependent and dependent animals. Addict Biol 18:812-825.

Houchi H, Warnault V, Barbier E, Dubois C, Pierrefiche O, Ledent C, Daoust M, Naassila M (2008) Involvement of A2A receptors in anxiolytic, locomotor and motivational properties of ethanol in mice. Genes Brain Behav 7:887-898.

Koob GF, Volkow ND (2010) Neurocircuitry of addiction. Neuropsychopharmacology 35:217-238.

Korstanje R, Paigen B (2002) From QTL to gene: the harvest begins. Nat Genet 31:235-236.

Lesscher HMB, Houthuijzen JM, Groot Koerkamp MJ, Holstege FC, Vanderschuren LJMJ (2012) Amygdala 14-3-3zeta as a novel modulator of escalating alcohol intake in mice. PLoS One 7:e37999.

Lesscher HMB, Kas MJ, van der Elst S, van Lith HA, Vanderschuren LJMJ (2009a) A grandparent-influenced locus for alcohol preference on mouse chromosome 2. Pharmacogenet Genomics 19:719-729.

Lesscher HMB, van Kerkhof LWM, Vanderschuren LJMJ (2010) Inflexible and indifferent alcohol drinking in male mice. Alcohol Clin Exp Res 34:1219-1225.

Lesscher HMB, Wallace MJ, Zeng L, Wang V, Deitchman JK, McMahon T, Messing RO, Newton PM (2009b) Amygdala protein kinase C epsilon controls alcohol consumption. Genes Brain Behav 8:493-499.

Maier SA, Galellis JR, McDermid HE (2005) Phylogenetic analysis reveals a novel protein family closely related to adenosine deaminase. J Mol Evol 61:776-794.

Milner LC, Buck KJ (2010) Identifying quantitative trait loci (QTLs) and genes (QTGs) for alcohol-related phenotypes in mice. Int Rev Neurobiol 91:173-204. 
Naassila M, Ledent C, Daoust M (2002) Low ethanol sensitivity and increased ethanol consumption in mice lacking adenosine $\mathrm{A} 2 \mathrm{~A}$ receptors. J Neurosci 22:10487-10493.

Nadeau JH, Singer JB, Matin A, Lander ES (2000) Analysing complex genetic traits with chromosome substitution strains. Nat Genet 24:221225.

Nam HW, Bruner RC, Choi DS (2013) Adenosine signaling in striatal circuits and alcohol use disorders. Mol Cells 36:195-202.

Neasta J, Ben Hamida S, Yowell QV, Carnicella S, Ron D (2011) AKT signaling pathway in the nucleus accumbens mediates excessive alcohol drinking behaviors. Biol Psychiatry 70:575-582.

Nelson AM, Battersby AS, Baghdoyan HA, Lydic R (2009) Opioid-induced decreases in rat brain adenosine levels are reversed by inhibiting adenosine deaminase. Anesthesiology 111:1327-1333.

Nie H, Rewal M, Gill TM, Ron D, Janak PH (2011) Extrasynaptic delta-containing GABAA receptors in the nucleus accumbens dorsomedial shell contribute to alcohol intake. Proc Natl Acad Sci U S A 108: 4459-4464.

Nikolskiy I, Conrad DF, Chun S, Fay JC, Cheverud JM, Lawson HA (2015) Using whole-genome sequences of the $\mathrm{LG} / \mathrm{J}$ and $\mathrm{SM} / \mathrm{J}$ inbred mouse strains to prioritize quantitative trait genes and nucleotides. BMC Genomics 16:415.

Noyes H, Brass A, Obara I, Anderson S, Archibald AL, Bradley DG, Fisher P, Freeman A, Gibson J, Gicheru M, Hall L, Hanotte O, Hulme H, McKeever D, Murray C, Oh SJ, Tate C, Smith K, Tapio M, Wambugu J, Williams DJ, Agaba M, Kemp SJ (2011) Genetic and expression analysis of cattle identifies candidate genes in pathways responding to Trypanosoma congolense infection. Proc Natl Acad Sci U S A 108:9304-9309.

Pandey SC, Zhang H, Ugale R, Prakash A, Xu T, Misra K (2008) Effector immediate-early gene arc in the amygdala plays a critical role in alcoholism. J Neurosci 28:2589-2600.

Peirce JL, Derr R, Shendure J, Kolata T, Silver LM (1998) A major influence of sex-specific loci on alcohol preference in $\mathrm{C} 57 \mathrm{Bl} / 6$ and DBA/2 inbred mice. Mamm Genome 9:942-948.

Phillips TJ, Belknap JK, Buck KJ, Cunningham CL (1998) Genes on mouse chromosomes 2 and 9 determine variation in ethanol consumption. Mamm Genome 9:936-941.

Pomierny-Chamiolo L, Rup K, Pomierny B, Niedzielska E, Kalivas PW, Filip M (2014) Metabotropic glutamatergic receptors and their ligands in drug addiction. Pharmacol Ther 142:281-305.

Porkka-Heiskanen T, Strecker RE, Thakkar M, Bjorkum AA, Greene RW, McCarley RW (1997) Adenosine: a mediator of the sleep-inducing effects of prolonged wakefulness. Science 276:1265-1268.

Rhodes JS, Best K, Belknap JK, Finn DA, Crabbe JC (2005) Evaluation of a simple model of ethanol drinking to intoxication in C57BL/6J mice. Physiol Behav 84:53-63.

Rhodes JS, Ford MM, Yu CH, Brown LL, Finn DA, Garland T Jr, Crabbe JC (2007) Mouse inbred strain differences in ethanol drinking to intoxication. Genes Brain Behav 6:1-18.

Rodriguez LA, Plomin R, Blizard DA, Jones BC, McClearn GE (1995) Alcohol acceptance, preference, and sensitivity in mice. II. Quantitative trait loci mapping analysis using BXD recombinant inbred strains. Alcohol Clin Exp Res 19:367-373.

Rosemberg DB, Rico EP, Guidoti MR, Dias RD, Souza DO, Bonan CD, Bogo MR (2007) Adenosine deaminase-related genes: molecular identification, tissue expression pattern and truncated alternative splice isoform in adult zebrafish (Danio rerio). Life Sci 81:1526-1534.
Schmidt LS, Miller AD, Lester DB, Bay-Richter C, Schulein C, FrikkeSchmidt H, Wess J, Blaha CD, Woldbye DP, Fink-Jensen A, Wortwein G (2010) Increased amphetamine-induced locomotor activity, sensitization, and accumbal dopamine release in M5 muscarinic receptor knockout mice. Psychopharmacology 207:547-558.

Schmittgen TD, Livak KJ (2008) Analyzing real-time PCR data by the comparative C(T) method. Nat Protoc 3:1101-1108.

Sebastiao AM, Ribeiro JA (2000) Fine-tuning neuromodulation by adenosine. Trends Pharmacol Sci 21:341-346.

Seif T, Simms JA, Lei K, Wegner S, Bonci A, Messing RO, Hopf FW (2015) D-Serine and D-Cycloserine reduce compulsive alcohol intake in rats. Neuropsychopharmacology 40:2357-2367.

Sogut I, Kanbak G (2010) In vitro effects of ethanol with aspirin on rat brain synaptosomes: the potential protective role of betaine. Int $\mathbf{J}$ Neurosci 120:774-783.

Spoelder M, Vanderschuren LJMJ, Lesscher HMB (2015) Individual variation in alcohol intake predicts reinforcement, motivation, and compulsive alcohol use in rats. Alcohol Clin Exp Res 39:2427-2437.

Tabakoff B, Hoffman PL (2013) The neurobiology of alcohol consumption and alcoholism: an integrative history. Pharmacol Biochem Behav 113:2037.

Tarantino LM, McClearn GE, Rodriguez LA, Plomin R (1998) Confirmation of quantitative trait loci for alcohol preference in mice. Alcohol Clin Exp Res 22:1099-1105.

Thomsen M, Woldbye DP, Wortwein G, Fink-Jensen A, Wess J, Caine SB (2005) Reduced cocaine self-administration in muscarinic M5 acetylcholine receptor-deficient mice. J Neurosci 25:8141-8149.

Thorsell A, Johnson J, Heilig M (2007) Effect of the adenosine A2a receptor antagonist 3,7-dimethyl-propargylxanthine on anxiety-like and depression-like behavior and alcohol consumption in Wistar Rats. Alcohol Clin Exp Res 31:1302-1307.

Vadasz C, Saito M, Gyetvai B, Mikics E, Vadasz C (2000) Scanning of five chromosomes for alcohol consumption loci. Alcohol 22:25-34.

Vanderschuren LJMJ, Minnaard AM, Smeets JAS, Lesscher HMB (2017) Punishment models of addictive behavior. Curr Opin Behav Sci 13:77-84.

Whatley VJ, Johnson TE, Erwin VG (1999) Identification and confirmation of quantitative trait loci regulating alcohol consumption in congenic strains of mice. Alcohol Clin Exp Res 23:1262-1271.

WHO (2011) Global Status Report on Alcohol and Health 2011. Available at: http://www.who.int/substance_abuse/publications/alcohol_2011/en/. Accessed May 21, 2017.

Woodson JC, Minor TR, Job RF (1998) Inhibition of adenosine deaminase by erythro-9-(2-hydroxy-3-nonyl)adenine (EHNA) mimics the effect of inescapable shock on escape learning in rats. Behav Neurosci 112:399-409.

Wurst W, Prakash N (2014) Wnt1-regulated genetic networks in midbrain dopaminergic neuron development. J Mol Cell Biol 6:34-41.

Yao L, Arolfo MP, Dohrman DP, Jiang Z, Fan P, Fuchs S, Janak PH, Gordon AS, Diamond I (2002) betagamma Dimers mediate synergy of dopamine D2 and adenosine A2 receptor-stimulated PKA signaling and regulate ethanol consumption. Cell 109:733-743.

Yoneyama N, Crabbe JC, Ford MM, Murillo A, Finn DA (2008) Voluntary ethanol consumption in 22 inbred mouse strains. Alcohol 42:149-160.

Ystrom E, Reichborn-Kjennerud T, Aggen SH, Kendler KS (2011) Alcohol dependence in men: reliability and heritability. Alcohol Clin Exp Res $35: 1716-1722$. 